\title{
Total Gas and Methane Evaluation of Rejected Mungbean Meal (Vigna radiata) with Jackfruit Leaves Addition
}

\author{
Sasongko WT ${ }^{1}$, Khurin'in ${ }^{2}$, Wahyono $\mathrm{T}^{1}$ \\ ${ }^{1}$ Agricultural Division, Center of Application for Isotopes and Radiation, National Nuclear Energy Agency \\ Jl. Lebak Bulus Raya No. 49, Cilandak, South Jakarta 12070, Indonesia \\ ${ }^{2}$ Science and Technology Faculty, Syarif Hidayatullah Islamic State University \\ Jl. Ir. H Juanda No. 95, Ciputat, Banten, Indonesia \\ wteguhs@batan.go.id
}

\begin{abstract}
Protein protection on rejected mungbean meal (RM) using tannins derived from jackfruit leaves is aplicable methods. The purpose of this study was to evaluate total gas and rumen fermentation characteristics of rejected mungbean meal with jacfruit leaves (JL) addition. Methane production was also observed to determine the efficiency of RM as feed after JL addition. Treatments consisted of RM (rejected mungbean meal), RM $+0.7 \% \mathrm{JL}$ and $\mathrm{RM}+1.4 \% \mathrm{JL}$. Experimental design was a completely randomized design with three treatments and three replicates. Gas production were measured at $0,2,4,6,8,10$, and $24 \mathrm{~h}$ of incubation. Methane production were measured after $24 \mathrm{~h}$ incubation. Rumen fluid-buffer was taken after $24 \mathrm{~h}$ incubation and analysed for $\mathrm{pH}, \mathrm{NH}_{3}$, total VFA, and protozoa population. Addition of either 0.7 and $1.4 \% \mathrm{JL}$ significantly reduced the total gas production at $24 \mathrm{~h}$ incubation. RM with $0.7 \% \mathrm{JL}$ addition reduced methane concentration (\%), methane production (ml/IVOMD) and protozoa population (cell/ml). It is concluded that addition of jackfruit leaves reduced optimum total gas production, while addition of either 0.7 and $1.4 \%$ jackfruit leaves reduced methane production and protozoa population. The best dose of jackfruit leaves to protect rejected mungbean meal is $0.7 \%$.
\end{abstract}

Key Words: Methane, Jackfruit Leaves, Rejected Mungbean Meal, Total Gas

\section{INTRODUCTION}

Agriculture byproduct are important feeds for domesticated ruminants in Indonesia. Rejected mungbean meal is one of the potential protein source that has not exploited well. Habibullah et al. (2007) reported that mungbean meal contained $20.8 \%$ crude protein (CP) and it can also fulfill the minerals deficiency. Chumpawadee et al. (2005) reported that mungbean meal contained $18.46 \%$ of CP but it has a low levels of rumen undegradable protein (RUDP) that is $34.31 \%$ and undegradable intake protein (UIP) $35.23 \%$. It is therefore suggested that rejected mungbean meal is a potential feed source but its protein should be protected from ruminal degradation. This is because protein is an expensive ingredients so that it must be used efficiently.

Protein passing through the rumen will be degraded by rumen microbes into smaller molecules such as peptides, amino acids and ammonia. These rumen degradation products will be used for rumen microbial protein synthesis. Proteins derived from microbes has not been able to meet the ruminant nutrient requirements. Therefore it is necessary to guarantee that part of the protein in feed could pass the rumen undegraded in the small intestine (Ali et al. 2009). Availability of protein in intestine is necessary for the host, espescially for growing, pregnant, birth, and lactating animal (Klopfenstein 2006). Protected protein feeding to lactating animals leads to increasing proportion of amino acids supply for productive and reproductive purpose (Shelke et al. 2012). Various treatments have been success in protecting dietary protein from ruminal degradation such as using formaldehyde (Dutta \& Agrawal 2000), chelate binding with mineral (Haryanto 2012) and 
organic protectants (tannin) (Bunglavan \& Dutta 2013). The use of formaldehyde and other chemical for protein protection are not enviromentally friendly way if applied in the organic farming (Bunglavan \& Dutta 2013). The best alternative is using organic protection such as condensed tannins as secondary metabolites that protecting protein from rumen degradation.

Protein protection using tannins in jackfruit leaves could be more aplicable. Since jackfruit trees growing in tropical climate and locally available for use by the farmer. It was reported that jackfruit leaves (leaf + petiole) containing $130 \mathrm{~g} / \mathrm{kg}$ condensed tannins (Kongmanila \& Ledin 2009). In vitro experiment is need to evaluate JL added in RM. In vitro gas test method has been selected for single feed screening and has a high correlation compared with in vivo methods (Menke et al. 1979; Getachew et al. 2000; Hamid et al. 2007). Therefore, the purpose of this study was to evaluate total gas and rumen fermentation product of rejected mungbean meal with jacfruit leaves addition. Methane production also observed to determine the effect of tannins derived from jackfruit leaves to improve efficiency of rejected mungbean meal fermentation.

\section{MATERIAL AND METHODS}

\section{Samples preparation and treatments}

Rejected mungbean meal and jackfruit leaves were dried at $60^{\circ} \mathrm{C}$ for three days and then ground to pass a fine particle size. Samples were analyzed for dry matter (DM), crude protein $(\mathrm{CP})$, ether extract (EE), crude fiber $(\mathrm{CF})$ and ash content by procedures of AOAC (2010). NDF and ADF were analyzed using Goering \& Van Soest (1970) procedures. Rumen fluid obtained from fistulated male buffalo.

\section{In vitro procedures}

Amounts of $380 \mathrm{mg}$ samples were weighed and transferred into $100 \mathrm{ml}$ syringe (Fortuna model, Germany). The rumen fluid was collected before the morning feeding from fistulated male buffalo fed on roughage and concentrate based diets (50:50 based on DM). The rumen fluid was strained and filtered use nylon cloth. The glasswares were kept at approximately $39^{\circ} \mathrm{C}$ before use. The substrates were added with $40 \mathrm{ml}$ of rumen fluidbuffer following the method of Menke et al. (1979) modification by Blümmel et al. (1997). The incubation was carried out at $39^{\circ} \mathrm{C}$ for $24 \mathrm{~h}$. All of measurements were repeated three times as replicate. Gas production measurements were performed at 0, 2, 4, 6, 8, 10, and $24 \mathrm{~h}$ incubation time. Methane production were measured after $24 \mathrm{~h}$ incubation. The rumen fluid-buffer contained in syringes were sampled for analysis of $\mathrm{pH}, \mathrm{NH}_{3}$, total VFA, and protozoa population.

\section{Experimental methods and data analysis}

Experimental design of this study was a completely randomized design with three treatments and three replicates. All treatments were described as follows: (1) RM (rejected mungbean meal); (2) $\mathrm{RM}+0.7 \%$ jackfruit leaves (DM); and (3) $\mathrm{RM}+1.4 \%$ jackfruit leaves $(\mathrm{DM})$.

Variables measured were total gas production after $0,2,4,6,8,10$, and $24 \mathrm{~h}$ incubation. Methane and carbondioxide production after $24 \mathrm{~h}$ incubation were determined using MRU gas analyzer ${ }^{\circledR}$. Measurement of $\mathrm{pH}$ was determined using Hanna instruments $\mathrm{pH}$ digital. Measurement of total VFA was done using AOAC (2010). $\mathrm{NH}_{3}$ measurement 
was conducted using Conway microdifusion methods. Protozoa population measurement was carried out according to the method of Ogimoto \& Imai (1981). Cumulative total gas production data were fitted to the model of Ørskov \& McDonald (1979) using software $\mathrm{NEWAY}^{\circledR}$ as follows:

$$
P=a+b\left(1-e^{-c t}\right)
$$

P: The gas production at time $\mathrm{t}$; a: The gas production from soluble fraction $(\mathrm{ml} / 380 \mathrm{mg} \mathrm{DM})$; b: The gas production from insoluble fraction $(\mathrm{ml} / 380 \mathrm{mg} \mathrm{DM})$; $\mathrm{c}$ : The gas production rate constant $(\mathrm{ml} / \mathrm{h}) ;(\mathrm{a}+\mathrm{b})$ : The potential gas production $(\mathrm{ml} / 380 \mathrm{mg} \mathrm{DM})$; $\mathrm{t}$ : The incubation time $(\mathrm{h})$

Effect of treatment was analyzed using SPSS 16.00 based the test of variance (ANOVA) and differences between treatment were analyzed using Duncan's Multiple Range Test (DMRT).

\section{RESULTS AND DISCUSSION}

\section{Total gas production}

Total gas production from the fermentation of rejected mungbean meal are presented in Figure 1. Total gas production at 2, 4, 6, 8 and $10 \mathrm{~h}$ incubation time were not significant. However, Adding both 0.7 and $1.4 \%$ jack fruit leaves (JL) significantly $(\mathrm{P}<0.05)$ reduced total gas production at $24 \mathrm{~h}$ incubation. in present study, JL could decreased total gas production after $10 \mathrm{~h}$ incubation. This result could be caused by the long time to protect protein. Ruminal microbes need adaption time (lag phase) before degrading the insoluble particle (Sofyan et al. 2015). However, potential gas production ( $a+b$ fraction) of $R M$ treatment still the highest one (Table 1).

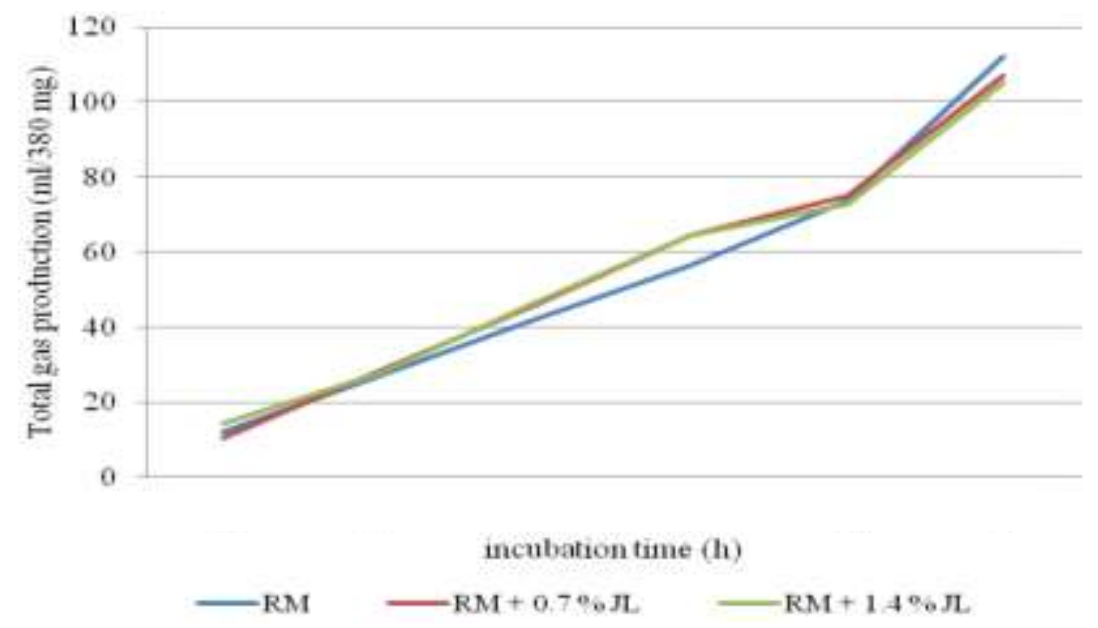

Figure 1. Total gas production of rejected mungbean meal with jackfruit leaves addition

The similar result was also reported by Serensinhe et al. (2012), that supplementation of condensed tannin could reduced forage fermentability as indicated by total gas production. Mohammadabadi \& Chaji (2011) using $30 \mathrm{~g}$ (DM) tannin extracted from oak leaves and pistachio. Low concentration of tannin addition $(0.5 \mathrm{mg} / \mathrm{ml}$ rumen fluid-buffer $)$ from mimosa and quebracho extract decreased total gas production of hay diet (Jayanegara et al. 2009). the reduced total gas production as affected by tannin could be due to inhibition mechanism on microbes enzym activity. The negative effect of tannins on digestion is not just the result of their interaction with macromolecules in the feeds, but 
also interference with fibrolytic and proteolytic enzymes. Tannins can reduce the nutritive value of feedstuffs and they can affect the health of the animal as well (Gürbüz et al. 2008). Gürbüz et al. (2008) also reported that gas is produced mainly when substrate is fermented to acetate and butyrate, therefore relatively lower gas production is associated with propionate production.

Table 1. Gas characteristics of rejected mungbean meal with jackfruit leaves addition

\begin{tabular}{lcccc}
\hline \hline Variables & $\mathrm{RM}$ & $\mathrm{RM}+0.7 \% \mathrm{JL}$ & $\mathrm{RM}+1.4 \% \mathrm{JL}$ & SEM \\
\hline $\mathrm{a}+\mathrm{b}(\mathrm{ml} / 380 \mathrm{mg} \mathrm{DM})$ & $133.180^{\mathrm{a}}$ & $115.850^{\mathrm{b}}$ & $114.740^{\mathrm{b}}$ & 3.599 \\
$\mathrm{c}(\mathrm{ml} / \mathrm{h})$ & $0.083^{\mathrm{b}}$ & $0.116^{\mathrm{a}}$ & $0.110^{\mathrm{a}}$ & 0.006 \\
$\mathrm{CH}_{4}(\%)$ & $13.980^{\mathrm{a}}$ & $9.860^{\mathrm{b}}$ & $13.610^{\mathrm{a}}$ & 0.694 \\
$\mathrm{CO}_{2}(\%)$ & 52.560 & 60.280 & 59.900 & 2.059 \\
$\mathrm{CH}_{4}(\mathrm{ml} / \mathrm{IVOMD})$ & $4.960^{\mathrm{a}}$ & $3.610^{\mathrm{b}}$ & $4.640^{\mathrm{a}}$ & 0.231 \\
$\mathrm{CO}_{2}(\mathrm{ml} / \mathrm{IVOMD})$ & 18.710 & 22.160 & 20.400 & 0.956 \\
$\mathrm{CO}_{2}: \mathrm{CH}_{4}$ & $3.770^{\mathrm{b}}$ & $6.120^{\mathrm{a}}$ & $4.430^{\mathrm{ab}}$ & 0.390 \\
\hline
\end{tabular}

$\mathrm{a}+\mathrm{b}$ : Potential gas production; c: Gas production rate; DM: Dry matter; RM: Rejected mungbean meal; IVOMD: In vitro organic matter digestibility; JL: Jackfruit leaves; SEM: Standard error of mean; Number with different superscript in the same row, significantly different with $\mathrm{P}<0.05$

\section{Gas characteristics}

Gas charecteristics evaluated by in vitro gas production were showed in Table 1. RM had higher potential total gas production $(\mathrm{a}+\mathrm{b})(\mathrm{P}<0.05)$ compared to the other. However, gas production rate (c) of RM treatment was the lowest compared to the others. RM with $0.7 \% \mathrm{JL}$ addition reduced both $\mathrm{CH}_{4}$ concentration (\%) and $\mathrm{CH}_{4}$ production (m/IVOMD) $(\mathrm{P}<0.05)$ but had no effect on $\mathrm{CO}_{2}$ concentration $(\%)$ and $\mathrm{CO}_{2}$ production (ml/IVOMD). $\mathrm{RM}$ with $0.7 \% \mathrm{JL}$ addition also had the highest efficiency of $\mathrm{C}$ utilization for $\mathrm{CO}_{2}$ production $\left(\mathrm{CO}_{2}: \mathrm{CH}_{4}\right.$ parameters $)(\mathrm{P}<0.05)$.

Fermentability evaluated by in vitro gas production was indicated by kinetics gas production parameters (Sofyan et al. 2015). Adding 0.7 and $1.4 \% \mathrm{JL}$ could reduce potential gas production from RM fermentation in the rumen. Pure tannin can reduce total gas production from insoluble fraction (b fraction) (Mohammadabadi \& Chaji 2011). Energy lost was reflected by high methane emission. Adding $0.7 \%$ JL could reduce methane emission from RM fermentation in the rumen that might be caused by tannins derived from JL. Tannins decrease the population of the principal actor of methanogenesis in the rumen (methanogens) (Jayanegara et al. 2015). Decrease in methane production also could be mediated through decrease in protozoal number (Table 2). Methanogens bacteria and protozoa have symbiotic relationship in the rumen (Morgavi et al. 2010). Bhatta et al. (2015) also reported that methane production was closely related to the protozoa number. Methane was generated by Archaea bacteria that consumed hydrogen. This bacteria activity have symbiotic with protozoa. The mechanism of effect of condensed tannin on methanogenesis is not completely understood. Tannin may be directly inhibit methanogen microbes growth in the rumen. Tannin also indirectly decreasing the nutrients availability for rumen microbes. Another possibility is that tannin is hydrogen acceptors and reduces the hydrogen availability for producing $\mathrm{CH}_{4}$ (Naumann et al. 2013). 


\section{Rumen fermentation products}

In vitro rumen fermentation products were presented in Table 2 . The $\mathrm{pH}$ values, $\mathrm{NH}_{3}$ concentration and TVFA concentration indicated that there were no significant different. However, adding $0.7 \% \mathrm{JL}$ could reduce protozoa population $(\mathrm{P}<0.05)$. The $\mathrm{NH}_{3}$ results were higher than optimal standard for closed-system culture microbes fermentation. The higher value caused by cumulation from RM fermentation product. Optimal concentration of $\mathrm{NH}_{3}$ for microbes fermentation in closed-system culture is $5 \mathrm{mg} / 100 \mathrm{ml}$, but it depends on the rate of feed fermentability (Wanapat \& Rowlison 2007; Wanapat et al. 2013).

Table 2. In vitro rumen fermentation product of rejected mungbean meal with jackfruit leaves addition

\begin{tabular}{lcccc}
\hline \hline Treatment & $\mathrm{pH}$ & $\mathrm{NH}_{3}(\mathrm{mg} / 100 \mathrm{ml})$ & TVFA $(\mathrm{mM})$ & Protozoa $\left(\times 10^{6} \mathrm{cell} / \mathrm{ml}\right)$ \\
\hline $\mathrm{RM}$ & 6.940 & 25.000 & 62.000 & $2.580^{\mathrm{a}}$ \\
$\mathrm{RM}+0.7 \% \mathrm{JL}$ & 6.840 & 35.000 & 49.330 & $1.420^{\mathrm{b}}$ \\
$\mathrm{RM}+1.4 \% \mathrm{JL}$ & 6.950 & 25.000 & 58.670 & $2.420^{\mathrm{ab}}$ \\
\hline $\mathrm{SEM}$ & 0.042 & 4.772 & 2.944 & 0.236 \\
\hline
\end{tabular}

RM: Rejected mungbean meal; SEM: Standard error of mean; TVFA: Total volatile fatty acid

Adding JL had no effect on TVFA production. In contrast, El-Waziry et al. (2007) studied that TVFA decrease significantly in soybean meal added with pure tannin. The addition of $0.5 \mathrm{mg} / \mathrm{ml}$ pure tannin on the substrate of haydiet can reduce TVFA production by $5.7-11.7 \%$. Tannin have a strong binding capacity for protein component, so it can protect from rumen degardation process (Cortes et al. 2009). Lower TVFA value is a reflection from the changes of rumen microbial population (Pamungkas et al. 2006). The contrast value from present study caused by the effect from the difference in the level of purity from tannin substrate. Protozoa population was reduced because the protozoa number was closely related with methane emission (Sofyan et al. 2015) (Table 2). Methanogens bacteria and protozoa have symbiotic relationship in the rumen (Morgavi et al. 2010).

\section{CONCLUSION}

Addition of jackfruit leaves reduced maximum total gas production. Addition of $0.7 \%$ jackfruit leaves also reduced methane production and protozoa population. Addition of $0.7 \% \mathrm{JL}$ has greater effects than addition at $1.4 \%$.

\section{ACKNOWLEDGEMENT}

The author wish to thank Shintia Nugrahini Wahyu Hardani, AMd., Dedi Ansori, Mar'atus Sholihah and all members in Animal Nutrition Laboratory. Gratitude is also expressed to Mr. Dinardi and others who helped in the field during this project.

\section{REFERENCES}

Ali CS, Din IU, Sharif M, Nisa M, Javaid A, Hashmi N, Sarwar M. 2009. Supplementation of ruminally protected proteins and amino acids: feed consumption, digestion and performance of cattle and sheep. Int J Agric Biol. 11:477-482. 
AOAC. 2010. Official methods of analysis of AOAC. 18 ${ }^{\text {th }}$ Ed. Rockville (US): AOAC International.

Bhatta R, Saravanan MM, Baruah L, Prasad CS. 2015. Effect of graded level of tannin-containing tropical tree leaves on in vitro rumen fermentation, total protozoa and methane production. $\mathrm{J}$ Appl Microbiol. 118:557-564.

Bunglavan SJ, Dutta N. 2013. Use of tannins as organic protectants of proteins in digestion of ruminants. J Livest Sci. 4:67-77.

Chumpawadee S, Sommart K, Vongpralub T, Pattarajinda V. 2005. Estimation of rumen undegradable protein with in situ nylon bag and in vitro enzymatic technique in tropical concentrate feedstuffs. Walaiak J Sci Tech 2:23-33.

Cortes JE, Morenob B, Pabón ML, Avila P, Kreuzerd M, Hess HD, Carulla JE. 2009. Effects of purified condensed tannins extracted from Calliandra, Flemingia and Leucaena on ruminal and postruminal degradation of soybean meal as estimated in vitro. Anim Feed Sci Technol. 151:194-204.

Dutta N, Agrawal IS. 2000. Effects of formaldehyde and heat treatment on protein degradability. Ind Vet J. 77:36-39.

El-Waziry AM, Nasser MEA, Sallam SMA, Abdallah AL, Bueno ICS. 2007. Processing methods of soybean meal. 2. Effect of autoclaving and Qucbraho tannin treated soybean meal on gas production and rumen fermentation in vitro. J Appl Sci. 3:17-24.

Getachew G, Makkar HPS, Becker K. 2000. Effect of polyethilene glycol on in vitro degradability and microbial protein synthesis from tannin-rich browse and herbaceous legumes. B J Nutr. 84:73-83.

Goering HK, Van Soest PJ. 1970. Forage fibre analysis (apparatus, reagents, procedures and some application). Washington DC (US): ARS USDA.

Gürbüz Y, Kaplan M, Davies DR. 2008. Effects of condensed tannin content on digestibility and determination of nutritive value of selected some native legumes species. J Anim Vet Adv. 7:854-862.

Habibullah, Abbas M, Shah HU. 2007. Proximate and mineral composition of mungbean. Sarhad J Agric. 23:463-466.

Hamid P, Akbar T, Hossein J, Ali MG. 2007. Nutrient digestibility and gas production of some tropical feeds used in ruminant diets estimated by the in vivo and in vitro gas production techniques. Am J Anim Vet Sci. 2:108-113.

Haryanto B. 2012. Perkembangan penelitian nutrisi ruminansia. Wartazoa. 22:169-177.

Jayanegara A, Goel G, Makkar HPS, Becker K. 2015. Divergence between purified hydrolysable and condensed tannin effects on methane emission, rumen fermentation and microbial population in vitro. Anim Feed Sci Tech. 209:60-68.

Jayanegara A, Makkar HPS, Becker K. 2009. Emisi metana dan fermentasi rumen in vitro ransum hay yang mengandung tanin murni pada konsentrasi rendah. Media Peternakan. 32:185-195.

Klopfenstein T. 2006. Need for escape protein by grazing cattle. Anim Feed Sci Tech. 60:191-199.

Kongmanila D, Ledin I. 2009. Chemical composition of some tropical foliage species and their intake and digestibility by goats. Asian Australas J Anim Sci. 22:803-811.

Menke KH, Raab L, Salewski A, Steingass H, Fritz, Schneider W. 1979. The estimation of the digestibility and metabolizable energy content of ruminant feeding stuffs from the gas production when they are incubated with rumen liquor. J Agric Sci. 93:217-222. 
Mohammadabadi T, Chaji M. 2012. The influence of the plant tannins on in vitro ruminal degradation and improving nutritive value of sunflower meal in ruminants. Pak Vet J. 32:225228.

Morgavi DP, Forano E, Martin C, Newbold CJ. 2010. Microbial ecosystem and methanogenesis in ruminants. Animal. 4:1024-1036.

Naumann HD, Muir JP, Lambert BD, Tedeschi LO, Kothmann MM. 2013. Condensed tannins in the ruminant environment: A perspective on biological activity. J Agr Sci. 1:8-20.

Ogimoto K, Imai S. 1981. Atlas of rumen microbiology. Tokyo (Japan): Japan Scientific Societies Press.

Ørskov ER, Mcdonald I. 1979. The estimation of protein degradability in the rumen from incubation measurements weighted according to the rate of passage. J Agr Sci Camb. 92:499503.

Pamungkas D, Sevilla CC, Lustria UM. 2006. Changes in rumen ecosystem and feed dry matter degradability of buffalo which received rumen content of cattle through cross inoculation. JITV. 11:24-33.

Serensinhe T, Madushika SAC, Serensinhe Y, Lal PK, Ørskov ER. 2012. Effects of tropical tannin non legume and low tannin legume browse mixtures on fermentation parameters and methanogenesis using gas production technique. Asian Australas J Anim Sci. 25:1404-1410.

Shelke SK, Thakur SS, Shete SM. 2012. Protected nutrients technology and the impact of feeding protected nutrients to dairy animals: A review. Int J Dairy Sci. 7:51-62.

Sofyan A, Sakti AA, Karimy MF, Julendra H, Istiqomah L, Herdian H, Damayanti E, Suryani AE. 2015. Effectivity of probiotic, micromineral enriched yeast and their combination with Azadirachta indica leaves containing tannin on fermentability and digestibility of Pennisetum hybrid. JITV. 20:95-104.

Wanapat M, Kang S, Phesatcha K. 2013. Enhancing buffalo production efficiency through rumen manipulation and nutrition. Buffalo Bull. 32:258-275.

Wanapat M, Rowlinson P. 2007. Nutrition and feeding of swamp buffalo: Feed resources and rumen approach. Ital J Anim Sci. 6:67-73. 